\title{
Reaction Characteristics of Organosolv-Fractionation Process for Selective Extraction of Carbohydrates and Lignin from Rice Husks
}

\author{
Tae Hoon Kim ${ }^{1,2}$, Hyun Kwak ${ }^{1}$, Tae Hyun Kim ${ }^{2, *(D)}$ and Kyeong Keun Oh ${ }^{1,3, *(D)}$ \\ 1 R\&D Center, SugarEn Co., Ltd., Yongin 16890, Gyeonggi-do, Korea; thkim@sugaren.co.kr (T.H.K.); \\ hkwak@sugaren.co.kr (H.K.) \\ 2 Department of Materials Science and Chemical Engineering, Hanyang University, Ansan 15588, \\ Gyeonggi-do, Korea \\ 3 Department of Chemical Engineering, Dankook University, Youngin 16890, Gyeonggi-do, Korea \\ * Correspondence: hitaehyun@hanyang.ac.kr (T.H.K.); kkoh@dankook.ac.kr (K.K.O.); \\ Tel.: +82-31-400-5222 (T.H.K.); +82-31-8005-3548 (K.K.O.)
}

\section{check for}

updates

Citation: Kim, T.H.; Kwak, H.; Kim, T.H.; Oh, K.K. Reaction Characteristics of Organosolv-Fractionation Process for Selective Extraction of

\section{Carbohydrates and Lignin from}

Rice Husks. Energies 2021, 14, 686. https://doi.org/10.3390/en14030686

Received: 30 November 2020

Accepted: 25 January 2021

Published: 29 January 2021

Publisher's Note: MDPI stays neutral with regard to jurisdictional claims in published maps and institutional affiliations.

Copyright: (c) 2021 by the authors. Licensee MDPI, Basel, Switzerland. This article is an open access article distributed under the terms and conditions of the Creative Commons Attribution (CC BY) license (https:/ / creativecommons.org/licenses/by/ $4.0 /)$.

\begin{abstract}
The organosolv-fractionation process can act as a biorefinery process because it can separate the main components of biomass, such as lignin and hemicellulose, with high purity. The ethanolbased organosolv-fractionation process was applied to separate carbohydrates and lignin from rice husks, and the extraction behavior was observed according to various reaction variables. Various reaction conditions such as different temperatures $\left(150{ }^{\circ} \mathrm{C}, 170{ }^{\circ} \mathrm{C}\right.$, and $\left.190{ }^{\circ} \mathrm{C}\right)$, reaction times (30 $\mathrm{min}, 60 \mathrm{~min}$, and $120 \mathrm{~min}$ ), and ethanol concentrations ( $40 \%, 60 \%$, and $80 \%$ ) were tested while maintaining the solid:liquid ratio (1:10) and sulfuric acid concentration ( $0.25 \mathrm{wt}$.\%). Two optimal reaction conditions for the target components were chosen: for sugar recovery, $150{ }^{\circ} \mathrm{C}, 60 \mathrm{~min}$, and $40 \%$ ethanol were used as condition 1 , and for lignin recovery, $170{ }^{\circ} \mathrm{C}, 120 \mathrm{~min}$, and $80 \%$ ethanol were used as condition 2 . Under condition $1,91.5 \%$ of the glucan was preserved in the residual solid, and $75.0 \%$ of the xylan was extracted from the liquid hydrolysate. For condition 2, 59.9\% of the lignin was recovered. To properly choose and apply the correct fractionation method and conditions, the reaction behavior (such as carbohydrate retention and extraction), lignin solubilization, and precipitation should be carefully considered.
\end{abstract}

Keywords: lignocellulosic biomass; rice husk; biorefinery; organosolv; fractionation

\section{Introduction}

In recent decades, lignocellulosic biomass (LCB), such as forest residue, agricultural byproducts, and energy crops has become the most abundant renewable resource, as one trillion tons of LCB have been generated worldwide [1]. LCB has been regarded as a promising substitute resource for traditional fossil fuels [2], with the economic and environmental benefits of sustainable development, the reutilization of waste resources, eco-friendly technology, and the maintenance of carbon neutrality $[3,4]$.

LCB generally consists of cellulose, hemicellulose, lignin, and several other minor components of protein, extractives (including waxes, fatty acids, gums, resins, chlorophyll, terpenoids, and phenolic substances), and inorganic minerals [5]. The chemical components differ depending on the species, which are attributed to the various physical and chemical properties in various LCBs. Even though a biomass may be of the same species, it will have different characteristics depending on the geographical location, harvested year, cultivation condition, and plant age [6]. Consequently, the diversity of LCB characteristics often complicates the implementation of biorefinery technology. To effectively utilize diverse LCBs as feedstock in biorefinery facilities and overcome their recalcitrant nature, choosing an adequate pretreatment process is essential. However, pretreatments constitute one of the most expensive operations in a biorefinery [5]. As a countermeasure to 
overcome the economic disadvantages in the pretreatment process, improvements in economic feasibility through the production of high-value-added byproducts from biomass are currently being studied [7,8]. Carbohydrates obtained by biorefining LCB are useful carbon sources that can be converted into high-value-added organic acids such as succinic acid, fumaric acid, malic acid, 2,5-furan dicarboxylic acid, 3-hydroxylpropionic acid, aspartic acid, glucaric acid, glutamic acid, itaconic acid, and levulinic acid, and sugar alcohols such as glycerol, sorbitol, xylitol, and arabinitol [7]. Lignin, a polyphenolic aromatic compound, can also be converted into fuels and chemicals such as syngas products, hydrocarbons, phenols, oxidized products, and macromolecule products [8]. However, to commercialize the production of high-value-added chemicals, an appropriate and effective fractionation technology should be applied to separate the three main components (cellulose, hemicellulose, and lignin) of the LCB into high-purity single substances. Various catalysts such as acids, alkalis, ionic liquids, and organic solvents have been studied as potential solvents for the fractionation process $[9,10]$; however, organic solvents are considered the most suitable solvents $[1,11]$. Specifically, the ethanol organosolv-fractionation process can recover high-purity cellulose from the treated solid and high-purity hemicellulose and lignin from liquid hydrolysate [12].

Rice, which is used as a staple food by half of the world's population, exists in two species, Oryza glaberrima (Steudel) and Oryza sativa (L.), and the latter is generally cultivated [13]. The annual global rice production is 715 million tons, of which approximately $90 \%$ is produced in Asia, and production is expected to increase owing to steady population growth $[14,15]$. On the other hand, approximately $25 \%$ of rice husks (RHs) are produced from paddy rice, totaling 180 million tons annually [14]. A sufficient supply of feedstock means that the price and quality stability of the raw materials are guaranteed. Despite their advantages as a feedstock, RHs are currently being burned in fields in most countries $[15,16]$. This practice wastes energy and generates serious environmental pollutants such as carbon dioxide, carbon monoxide, and nitrogen oxide [17,18]. Therefore, various efforts to utilize RHs as a useful resource for biorefining have considerably raised expectations with regards to environmental and economic feasibility.

Among these efforts, there have been studies for effective fractionation methods for LCB using organosolv [8], but most have focused on a single target substance such as cellulose or lignin. In this study, we simultaneously investigated the overall reaction behavior of the three major components of RHs during organosolv-fractionation processing, as well as observing the correlation of each component with various reaction parameters such as the reaction temperature, reaction time, and ethanol concentration. By exploring various reaction parameters, the optimal reaction conditions for separating the three main components of RHs with high purity were established. The topics discussed in this study can contribute to the interpretation of phenomena that may arise during the organosolvfractionation process.

\section{Materials and Methods}

\subsection{Materials}

RHs were provided by the National Institute of Crop Science, Rural Development Administration (NICS-RDA, Wanju, Jeollabuk-do, Korea). The RHs were dried using a convection oven at $45 \pm 5^{\circ} \mathrm{C}$ for $48 \mathrm{~h}$ and then stored in an automatic dehumidification desiccator until used. The average moisture content of the dried RHs was $6.8 \%$. The composition of the RHs was determined using the LAP (Laboratory Standard Procedure) of the NREL (National Renewable Energy Laboratory, Golden, CO, USA) [19-22]. The chemical composition of the untreated RHs was 35.6\% glucan, $13.6 \%$ xylan, $1.7 \%$ arabinan, $22.7 \%$ acid-insoluble lignin (AIL), $0.7 \%$ acid-soluble lignin (ASL), $1.2 \%$ ethanol extractives, $6.6 \%$ water extractives, $2.3 \%$ protein, and $15.7 \%$ ash $(n=3$, standard deviations $<0.8)$.

Ethanol (cat. no. E7023), tetrahydrofuran (THF, cat. no. 401757), pyridine (cat. no. 270970), chloroform-d (cat. no. 151858), cyclohexanol (cat. no. 105899), chromium(III) 
acetylacetonate (cat. no. 574082), and 2-chloro-4,4,5,5-tetramethyl-1,2,3-dioxaphospholane (TMDP, cat. no. 447536) were purchased from Sigma-Aldrich (St. Louis, MO, USA).

\subsection{Experimental Setup and Operation}

RHs were treated under various reaction conditions, i.e., reaction temperatures (150, 170 , and $190^{\circ} \mathrm{C}$ ), reaction times (30 $\mathrm{min}, 60 \mathrm{~min}$, and $120 \mathrm{~min}$ ) and ethanol concentrations $(40 \%, 60 \%$, and $80 \%)$ The sulfuric acid concentration and solid-to-liquid ratio were fixed at $0.25 \%(w / v)$ and $1: 10$, respectively. In the organosolv process using ethanol, sulfuric acid was added as a catalyst to increase the rate of lignin solubilization and reduce the reaction severity because sulfuric acid cleaves acid-labile bonds ( $\alpha$-aryl ether and aryl glycerol- $\beta$-aryl ether bonds) [23]. The stainless-steel batch reactor used for the organosolvfractionation process consisted of a preheating bath (molten salt bath), reaction baths (silicone oil baths), and a cooling bath (water bath). The molten salt bath was set to $250^{\circ} \mathrm{C}$, a high temperature, to minimize the preheating time needed to reach the target temperature. The temperatures of the silicon oil bath and water bath were set to the target temperature $\left(150{ }^{\circ} \mathrm{C}, 170{ }^{\circ} \mathrm{C}\right.$, or $\left.190{ }^{\circ} \mathrm{C}\right)$ and $30^{\circ} \mathrm{C}$, respectively. Forty grams of RHs and $60 \%(v / v)$ ethanol (with $0.25 \%(w / v) \mathrm{H}_{2} \mathrm{SO}_{4}$ ) were packed into a bomb tubular type reactor. The reactor was placed in a molten salt bath for preheating. When the reactor reached the target temperature in that molten salt bath, the reactor was transferred to a silicone oil bath for maintaining the reaction temperature. After the completion of the reaction, the reactor was placed in a water bath for cooling. The average preheating time was less than $3.0 \mathrm{~min}$ under all the investigated reaction temperature conditions. The bomb tubular reactor was constructed from SS-316L tubing with a $21.0 \mathrm{~mm}$ ID (inner diameter) and a $140 \mathrm{~mm}$ length (48.5 $\mathrm{cm}^{3}$ internal volume). The temperatures of the reaction baths and reactors were measured and monitored continuously using high-temperature thermocouples (cat. no. HY-72D, Korea Hanyoung Co. Ltd., Incheon, Korea). A timer and movement controller were used to control the reaction time and movement of the reactors, respectively.

Upon the completion of the reaction, the liquid samples were removed from the reactor, deionized (DI) water was added so that the final ethanol concentration was less than $20 \%$ to precipitate lignin, and the lignin were separated by a centrifuge. The separated liquid samples were placed in a drying oven at $55^{\circ} \mathrm{C}$ for the evaporation of residual ethanol and analyzed to determine their concentrations of carbohydrates (i.e., glucose and xylose) and byproducts (i.e., formic acid, acetic acid, levulinic acid, 5-HMF (hydroxymethylfurfural), and furfural). The separated lignin samples were dried at $45{ }^{\circ} \mathrm{C}$ for $12 \mathrm{~h}$, and then, precipitation yield calculations and purity analysis were performed. The fractionated solids removed from the reactor were filtered, dried (at $45^{\circ} \mathrm{C}$ for $12 \mathrm{~h}$ ), and then subjected to weight-loss measurements and composition analysis.

The delignification yield was calculated using the following equation:

$$
\text { Delignification yield }(\%)=\frac{\text { lignin in treated } \mathrm{RH}(\mathrm{g}) \times\left(1-\left(\frac{\text { solid output }(\mathrm{g})}{\text { solid input }(\mathrm{g})}\right)\right)}{\text { lignin in untreated } \mathrm{RH}(\mathrm{g})} \times 100
$$

A previous study has reported that the adjustment of the ethanol concentration was effective for precipitating lignin from ethanol organosolv liquid hydrolysate [24]. The lignin's solubility in a $20 \%$ ethanol solution (with water) is less than $0.46 \%$ [25]. The treated liquid hydrolysates $(40 \%, 60 \%$, and $80 \%$ ethanol) were diluted with DI water so that the final ethanol concentrations were less than $20 \%$. The lignin precipitation yield was calculated using the following equation:

$$
\text { Lignin precipitation yield }(\%)=\frac{\text { precipitated lignin }(\mathrm{g})}{\text { lignin in liquid hydrolyzate }(\mathrm{g})} \times 100
$$




\subsection{Composition Analysis of Untreated and Treated Rice Husks}

The chemical compositions of the solid and liquid samples were determined according to the procedures of the NREL-LAP [19-22]. For the untreated RHs, the extractions were carried out in two steps using water and ethanol consecutively. For the composition analysis of the extractive-free (untreated) and treated solids, two-step acid hydrolysis was carried out to determine the carbohydrate (sugar) and lignin contents.

A high-pressure liquid chromatography (HPLC) system (model LC-10A, Shimadzu Inc., Kyoto, Japan) with a refractive index (RI) detector (model RID-10A, Shimadzu Inc., Kyoto, Japan) was used to determine the carbohydrate and byproduct components of the samples. For the analysis of monomeric sugars from the untreated and treated $\mathrm{RH}$ samples, a carbohydrate column (Aminex HPX-87P, Bio-Rad Inc., Hercules, CA, USA) was used; HPLC-grade water was used as the mobile phase with a volumetric flow rate of $0.6 \mathrm{~mL} / \mathrm{min}$. The operating temperature of the column was $80^{\circ} \mathrm{C}$. The liquid hydrolysis samples were analyzed using an organic acid column (Aminex HPX-87H, Bio-Rad Inc., Hercules, CA, USA); $5 \mathrm{mM}$ sulfuric acid was used as the mobile phase, with a volumetric flow rate of $0.5 \mathrm{~mL} / \mathrm{min}$. Prior to the HPLC analysis, the samples were neutralized with calcium carbonate and filtered $(0.45 \mu \mathrm{m}$ pore size). The operating temperature of the column for the HPLC analysis was $65^{\circ} \mathrm{C}$.

\subsection{Reaction Severity}

In this study, $\log R_{0}$ was applied to determine the reaction severity to account for the behaviors of glucan, xylan, and lignin after the fractionation process. The concept of reaction severity, which combines reaction time and temperature, is often used in biomass research. The severity factor was defined by Overend and Chormet [26] as follows.

$$
\log R_{0}=\log \left[t \times \operatorname{Exp} \frac{(T-100)}{14.75}\right]
$$

where $t$ is the time ( $\mathrm{min}), T$ is the temperature $\left({ }^{\circ} \mathrm{C}\right)$, and 14.75 is an empirical parameter related to the activation energy and temperature. Table 1 summarizes reaction conditions and their reaction severities $\left(\log R_{0}\right)$ tested in this study.

Table 1. Reaction severities vs. reaction temperatures and times.

\begin{tabular}{ccc}
\hline \multicolumn{2}{c}{ Reaction Conditions } & \multirow{1}{*}{$\log \boldsymbol{R}_{\mathbf{0}}(-)$} \\
\cline { 1 - 2 } Temperature $\left({ }^{\circ} \mathbf{C}\right)$ & Time (min) & 2.95 \\
\multirow{2}{*}{150} & 30 & 3.25 \\
& 60 & 3.55 \\
\hline \multirow{2}{*}{170} & 120 & 3.54 \\
& 30 & 3.84 \\
\multirow{2}{*}{190} & 60 & 4.14 \\
\hline & 120 & 4.13 \\
& 30 & 4.43 \\
& 60 & 4.73 \\
\hline
\end{tabular}

\subsection{Crystallinity Measurement}

The crystallinity of the treated RHs was determined via X-ray diffraction (Rigaku Co., Tokyo, Japan) with operating conditions of $40 \mathrm{kV}$ and $40 \mathrm{~mA}$. The samples were scanned at $4^{\circ} / \min \left(2 \theta=10-35^{\circ}, 0.02\right.$ increments). The crystallinity index ( $\left.\mathrm{CrI}\right)$ of the samples was calculated using the following equation [27]:

$$
\operatorname{CrI}=\left[\frac{I_{002}-I_{18}}{I_{002}}\right] \times 100
$$


where $I_{002}$ is the peak intensity corresponding to the 002 lattice plane of cellulose molecules observed at $2 \theta=22.5^{\circ}$, and I18 (at $2 \theta=18^{\circ}$ ) is the peak intensity corresponding to amorphous cellulose.

\subsection{Chemical Properties of Precipitated Lignin}

The number-average molar mass $\left(M_{n}\right)$, weight-average molar mass $\left(M_{w}\right)$, and polydispersity (PD) of the organosolv-fractionated lignin samples were determined via gel permeation chromatography (GPC, Ultimate 3000, Thermo Fisher Scientific Inc., Waltham, MA, USA). For the molecular weight determination, $3 \mathrm{mg}$ of lignin was dissolved in $2 \mathrm{~mL}$ of THF and filtered with a $0.45 \mu \mathrm{m}$ polytetrafluoroethylene (PTFE) syringe filter to remove impurities. The GPC system was equipped with a Shodex column (KF-806L with a Shodex KF-G guard column) and an RI detector (Refracto Max 520). THF was used as the mobile phase $(1.0 \mathrm{~mL} / \mathrm{min})$, and the injection volume was $20 \mu \mathrm{L}$. The $M_{n}$ and $M_{w}$ of the precipitated lignin were calculated using the following equation.

$$
\begin{gathered}
M_{n}=\frac{\sum N_{i} M_{i}}{\sum N_{i}} \\
M_{w}=\frac{\sum N_{i} M_{i}^{2}}{\sum N_{i} M_{i}}
\end{gathered}
$$

where the index number, $i$, represents the number of different molecular weights present in the lignin sample and $N_{i}$ is the total number of moles with the molar mass of $M_{i}$.

The recording of ${ }^{31} \mathrm{P}$ nuclear magnetic resonance (NMR) (model Avance 600, Bruker Corp., Billerica, MA, USA) spectra was performed at $242.88 \mathrm{MHz}$ and with 256 scans with a $2 \mathrm{~s}$ pulse delay. For a quantitative ${ }^{31} \mathrm{P}$ NMR analysis, $20 \mathrm{mg}$ of lignin sample was accurately weighed and dissolved in $400 \mu \mathrm{L}$ of solution $\mathrm{A}$ and $150 \mu \mathrm{L}$ of solution $\mathrm{B}$ in a $5 \mathrm{~mL}$ vial. Solution A was a mixture of pyridine and chloroform-d $\left(\mathrm{CDCl}_{3}\right)$ at a ratio of 1.6:1 (v/v). Solution B was a mixture of solution A (25 mL), cyclohexanol (100 mg), and chromium (III) acetylacetonate $(90 \mathrm{mg}$ ). The dissolved liquid was vortexed for $5 \mathrm{~min}, 70 \mu \mathrm{L}$ of TMDP was added to the solution, and the resultant mixture was analyzed using the ${ }^{31} \mathrm{P}$ NMR system. The quantification of hydroxyl groups was performed based on the integrated peak areas of an internal standard (cyclohexanol).

\section{Results and Discussion}

\subsection{Organosolv Fractionation of Rice Husks}

\subsubsection{Delignification Behavior}

The effects of the reaction severity on the delignification of RHs via organosolv fractionation at various ethanol concentrations are presented in Figure 1. In this comparison, nine different residual solid samples were analyzed via the NREL-LAP procedure for lignin analysis [20], and the delignification yield was plotted against $\log R_{0}$. As seen in Figure 1, the delignification increased as $\log R_{0}$ increased from 2.95 to 4.73 , and the ethanol concentration increased from $40 \%$ to $80 \%$. In addition, all three ethanol concentrations resulted in similar delignification patterns; however, the overall delignification yields were lower with the $40 \%$ ethanol concentration compared to the other concentrations. Although the ethanol concentration significantly affects the delignification performance, the reaction severity (a function of the reaction temperature and time) could be a more influential variable in this range of ethanol concentrations (40-80\%), which was assumed to be related to the cleavage of the lignin and carbohydrate complex under severe reaction conditions [23]. This complex can be measured as AIL after compositional analysis using two-step acid hydrolysis. Lignin forms a lignin-carbohydrate complex by forming an $\alpha-\mathrm{O}-4$ bond with hemicellulose in the cell wall [23]. This $\alpha-\mathrm{O}-4$ bond is easily broken under severe reaction conditions (high $\log R_{0}$ ) by the decrease in the $\mathrm{pH}$ during the reaction. Consequently, additional lignin would have been extracted by breaking the $\alpha-\mathrm{O}-4$ bond with hemicellulose at a high reaction severity. At the highest $\log R_{0}$ of 4.73 , the delignification yields of the 
$40 \%, 60 \%$, and $80 \%$ ethanol concentration were $70.6 \%, 86.0 \%$, and $90.7 \%$, respectively. Comparing with previous studies using other organic solvents for rice husk delignification, this suggests that the ethanol-sulfuric acid solvent is more effective. For example, in other studies using 1,4-butanediol [18] and ethanol-soda [28] as organic solvents for rice husk delignification, $86.0 \%$ and $90.1 \%$ delignification yields were obtained, respectively. However, these two processes require acid hydrolysis pretreatment, which leads to process complexity and economic penalties. On the other hand, the ethanol-sulfuric acid solvent used in this study can effectively separate organosolv lignin in a single process. The highest delignification yield was obtained by the treatment with an $80 \%$ ethanol concentration; however, considering economic demands, the reaction using $60 \%$ ethanol would be the most preferable.

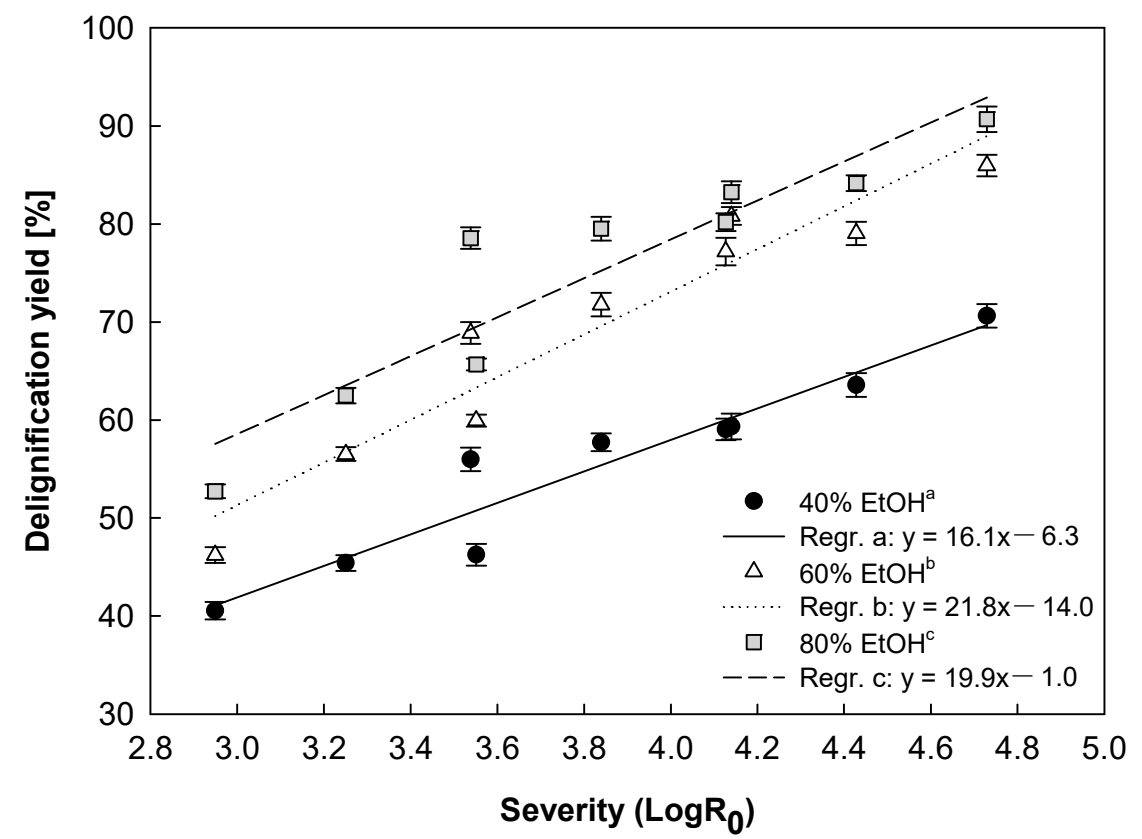

Figure 1. Delignification yield with reaction severity $\left(\log R_{0}\right.$ from 2.95 to 4.73$)$ and ethanol concentration. Reaction conditions: $150{ }^{\circ} \mathrm{C}, 170{ }^{\circ} \mathrm{C}$, and $190{ }^{\circ} \mathrm{C}$ for temperature; $30 \mathrm{~min}, 60 \mathrm{~min}$, and $120 \mathrm{~min}$ for time; and $40 \%, 60 \%$, and $80 \%$ for ethanol concentrations; solid:liquid $=1: 10 ; 0.25 \mathrm{wt}$. $\%$ sulfuric acid concentration.

In comparing similar $\log R_{0}$ values, it was found that the variables had a significant effect on the delignification yield. As shown in Figure 1, the delignification varied despite the same $\log R_{0}$ (3.54-3.55 and 4.13-4.14) at all the ethanol concentrations. For example, the two reaction conditions at $\log R_{0} 3.54$ and 3.55 with a $40 \%$ ethanol concentration were $150{ }^{\circ} \mathrm{C}$ and $120 \mathrm{~min}$, and $170{ }^{\circ} \mathrm{C}$ and $30 \mathrm{~min}$, and their delignification yields were $46.3 \%$ and $56.0 \%$, respectively. This indicates that the reaction temperature has a greater influence on the delignification yield than the reaction time. Therefore, to achieve maximum delignification in organosolv fractionation, an appropriate combination of reaction temperature and ethanol concentration should be selected.

\subsubsection{Lignin Precipitation Behavior}

The precipitated lignin was obtained from the liquid hydrolysate by the addition of water to the hydrolysate. The precipitation yield with $\log R_{0}$ is presented in Figure 2, which shows that an increase in ethanol concentration enhanced the lignin precipitation yield, but the $60 \%$ and $80 \%$ ethanol concentrations did not show any significant results for precipitation yield. This means that fractionation using a $60 \%$ ethanol concentration resulted in an increase in precipitated lignin, which indicates that the ethanol concentration $(\sim 60 \%)$ was sufficient for extracting lignin. By contrast, increasing $\log R_{0}$ decreased the 
lignin precipitation yield for the fractionations with ethanol concentrations of $60 \%$ and $80 \%$. According to the above result (in Section 3.1.1), increasing $\log R_{0}$ generally improved delignification. This means that the severest reaction conditions (high $\log R_{0}$ ) improved delignification, whereas they decreased lignin precipitation (lignin recovery as solid). The reason for the decreased precipitation yields despite the high delignification yield under the severest reaction conditions may be the formation of lignin fragments during the reaction. The severe reaction conditions break the $\alpha$ - and $\beta$-ether linkages in lignin and form a small lignin fragment [29]. A lower molecular size of lignin was produced under severe conditions; this lignin is likely to be difficult to recover and would consequently decrease the lignin precipitation yield. The correlation between the lignin molecular weight and reaction severity can be confirmed via molecular weight analysis (see Section 3.1.3 for more details). The highest lignin precipitation yield (77.5\%) was obtained with a $\log R_{0}$ of 2.95 and an $80 \%$ ethanol concentration. To obtain the highest lignin recovery yield in the organosolv fractionation, both delignification and consequent lignin precipitation must be considered, which means that the ethanol concentration and reaction severity should be equally evaluated as critical variables.

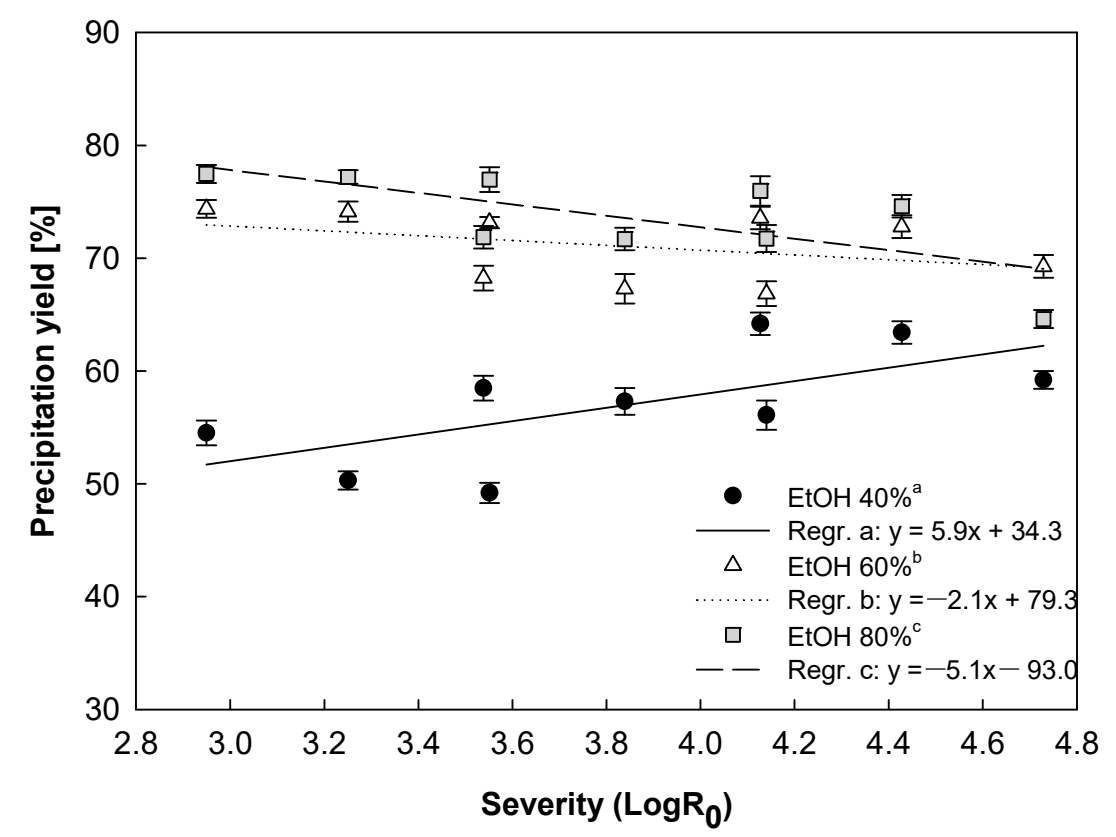

Figure 2. Lignin precipitation yield based on reaction severity ( $\log R_{0}$ from 2.95 to 4.73 ) and ethanol concentration. Reaction conditions: $150{ }^{\circ} \mathrm{C}, 170{ }^{\circ} \mathrm{C}$, and $190^{\circ} \mathrm{C}$ for temperature; $30 \mathrm{~min}, 60 \mathrm{~min}$, and $120 \mathrm{~min}$ for time; and $40 \%, 60 \%$, and $80 \%$ for ethanol concentrations; solid:liquid = 1:10; $0.25 \mathrm{wt}$. $\%$ sulfuric acid concentration.

Table 2 summarizes the reaction conditions and their results in previous studies for the various organosolv treatments of rice husk. 
Table 2. Previous reports on lignin removal from rice husks using organosolv method.

\begin{tabular}{|c|c|c|c|c|c|c|}
\hline Solvent & Catalyst & Conditions & Target Component & Yield/Effect & Remarks & Ref. \\
\hline $\begin{array}{c}1,4- \\
\text { Butanefiol }\end{array}$ & $\mathrm{H}_{2} \mathrm{SO}_{4}$ & $\begin{array}{l}190-210{ }^{\circ} \mathrm{C} \text { for } 2-6 \mathrm{~h} \text {; } \\
\text { 1,4-butanediol } \\
(70-90 \%), \mathrm{H}_{2} \mathrm{SO}_{4} \\
(0.2-0.35 \%) ; \mathrm{L} / \mathrm{S}=8-12\end{array}$ & $\begin{array}{l}\text { To separate glucan, } \\
\text { xylan, lignin, silica; } \\
\text { to generate ethanol }\end{array}$ & $\begin{array}{l}\text { Delignification } \\
(86.0 \%), \text { xylose } \\
\text { extraction }(71.6 \%), \\
\text { cellulose-to-glucose } \\
(58.4 \%), \text { ethanol yield } \\
(45 \%)\end{array}$ & $\begin{array}{l}\text { No organosolv used; } \\
\text { acid-treated biomass } \\
\text { was then fractionated } \\
\text { using 1,4-butanediol as } \\
\text { solvent for lignin } \\
\text { solubilization }\end{array}$ & [18] \\
\hline $\begin{array}{c}\text { Ethanol + } \\
\mathrm{NaOH}\end{array}$ & $\mathrm{H}_{2} \mathrm{SO}_{4}$ & $\begin{array}{l}160{ }^{\circ} \mathrm{C} \text { for } 1 \mathrm{~h} \text {; ethanol } \\
(26-60 \%)+\mathrm{NaOH} \\
(0.9-1.7 \%) ; \mathrm{L} / \mathrm{S}=10\end{array}$ & $\begin{array}{l}\text { To separate lignin } \\
\text { and inorganics } \\
\text { (silica) }\end{array}$ & $\begin{array}{l}\text { Delignification } \\
(90.1 \%), \text { inorganics } \\
(40 \%)\end{array}$ & $\begin{array}{l}\text { Acid-treated biomass } \\
\text { was then fractionated } \\
\text { using ethanol-soda as } \\
\text { solvent for } \\
\text { lignin removal }\end{array}$ & [28] \\
\hline Ethanol & $\mathrm{H}_{2} \mathrm{SO}_{4}$ & $\begin{array}{l}170-190{ }^{\circ} \mathrm{C} \text { for } 1 \mathrm{~h} ; \\
\text { ethanol }(50-70 \%)+ \\
\mathrm{H}_{2} \mathrm{SO}_{4}(0.15-0.7 \%) ; \\
\mathrm{L} / \mathrm{S}=10\end{array}$ & $\begin{array}{l}\text { To separate glucan, } \\
\text { xylan, and lignin }\end{array}$ & $\begin{array}{l}\text { Delignification } \\
(77.5 \%), x y l o s e \\
\text { extraction }(69.1 \%), \\
\text { cellulose-to-glucose } \\
(76.1 \%)\end{array}$ & $\begin{array}{l}\text { No precipitation } \\
\text { yield reported }\end{array}$ & [30] \\
\hline Ethanol & $\mathrm{H}_{2} \mathrm{SO}_{4}$ & $\begin{array}{l}180{ }^{\circ} \mathrm{C} \text { for } 1 \mathrm{~h} \text {; ethanol } \\
(50 \%)+\mathrm{H}_{2} \mathrm{SO}_{4}(0.01 \%) \\
\mathrm{L} / \mathrm{S} \text { ratio }=7.5\end{array}$ & $\begin{array}{l}\text { To generate } \\
\text { aromatic products } \\
\text { (THF, EtOAc, DEE) } \\
\text { using hydrolysate } \\
\text { conversion }\end{array}$ & $\begin{array}{l}\text { No yield reported; } \\
\text { cellulose, } \\
\text { hemicellulose, and } \\
\text { lignin (no data) }\end{array}$ & $\begin{array}{l}\text { Ionic liquid was used } \\
\text { for further conversion } \\
\text { of THF, EtOAc, } \\
\text { and DEE }\end{array}$ & [31] \\
\hline Ethanol & $\mathrm{H}_{2} \mathrm{SO}_{4}$ & $\begin{array}{l}180{ }^{\circ} \mathrm{C} \text { for } 1 \mathrm{~h} \text {; ethanol } \\
(50 \%)+\mathrm{H}_{2} \mathrm{SO}_{4}(0.17 \%) \\
\mathrm{L} / \mathrm{S} \text { ratio }=7.5\end{array}$ & To separate lignin & $\begin{array}{l}\text { No yield reported; } \\
\text { cellulose, } \\
\text { hemicellulose, and } \\
\text { lignin (no data) }\end{array}$ & $\begin{array}{l}\text { Focused on lignin } \\
\text { characteristics }\end{array}$ & [32] \\
\hline Ethanol & $\mathrm{H}_{2} \mathrm{SO}_{4}$ & $\begin{array}{l}150-190{ }^{\circ} \mathrm{C} \text {, for } 0.5-2 \mathrm{~h} \text {; } \\
\text { ethanol }(40-80 \%)+ \\
\mathrm{H}_{2} \mathrm{SO}_{4}(0.25 \%) ; \mathrm{L} / \mathrm{S}=10\end{array}$ & $\begin{array}{l}\text { To precipitate } \\
\text { lignin in solid form }\end{array}$ & $\begin{array}{l}\text { Delignification } \\
(83.3 \%), \text { lignin } \\
\text { precipitation }(71.7 \%), \\
\text { xylan extraction } \\
(75.0 \%)\end{array}$ & $\begin{array}{l}\text { Selective extraction of } \\
\text { each component of } \\
\text { rice husks }\end{array}$ & $\begin{array}{l}\text { This } \\
\text { work }\end{array}$ \\
\hline
\end{tabular}

\subsubsection{Carbohydrate and Byproduct Behavior}

To understand the extraction characteristics of cellulose and hemicellulose (mainly xylan/xylose in RHs) under various reaction conditions, the glucan and xylan contents based on untreated content for $\log R_{0}$ are presented in Figure 3 . As shown in the figure, the glucan content of the residual solid decreased as $\log R_{0}$ increased from 2.95 to 4.73 . Therefore, the glucan content likely decreases with increasing reaction severity. At the same $\log R_{0}$ of 2.95 , the glucan contents after treatment with ethanol concentrations of $40 \%, 60 \%$, and $80 \%$ were similar, at $91.0 \%, 90.4 \%$, and $90.2 \%$, respectively. However, when the $\log R_{0}$ increased to 4.73 , the glucan contents after treatment using the same concentrations showed significant differences, at 79.2\%, 74.2\%, and 63.8\%, respectively. This indicates that only under severe conditions does increasing the ethanol concentration decrease the glucan content in the residual solid. As shown in the liquid hydrolysate analysis in Table 3, under severe conditions, the glucan content increasingly dissolved as the ethanol concentration increased. We suggest that an increase in ethanol concentration lowers the reaction severity, but the results in Figure 3 appear to suggest an increase in the reaction severity. This is likely to be related to the transformation of the residual solid crystallinity during the reaction. The native cellulose of plants exists in both crystalline $\left(I_{\alpha}\right.$ and $\left.I_{\beta}\right)$ and non-crystalline forms. The crystalline part can be converted to a para-crystalline or amorphous form when treated with ethanol in the presence of acid catalysis [1]. Therefore, an increase in ethanol concentration is likely to disrupt the crystallinity of native cellulose, and consequently, more cellulose could be hydrolyzed and dissolved into the liquid hydrolysate. Another hypothesis is that at the high ethanol concentrations, the exposure of the amorphous part increased owing to the dissolution of a large amount of lignin, 
and hence, cellulose could be increasingly dissolved. As shown in Figure 4a, the CrI value of the organosolv-treated residual solid increased from 20.1 to 56.3 as the ethanol concentration increased from $40 \%$ to $80 \%$. Higher concentrations of ethanol cause the exposure of amorphous cellulose through the increased removal of other components such as hemicellulose and lignin, dissolving amorphous cellulose into a liquid, leaving only the more crystalline parts. By contrast, a decrease in CrI depending on the reaction severity $\left(\log R_{0}\right)$ is a phenomenon commonly seen in the biomass pretreatment process. Increasing the reaction severity interferes with the hemicellulose and lignin of the biomass, leading to a decrease in the crystallinity.

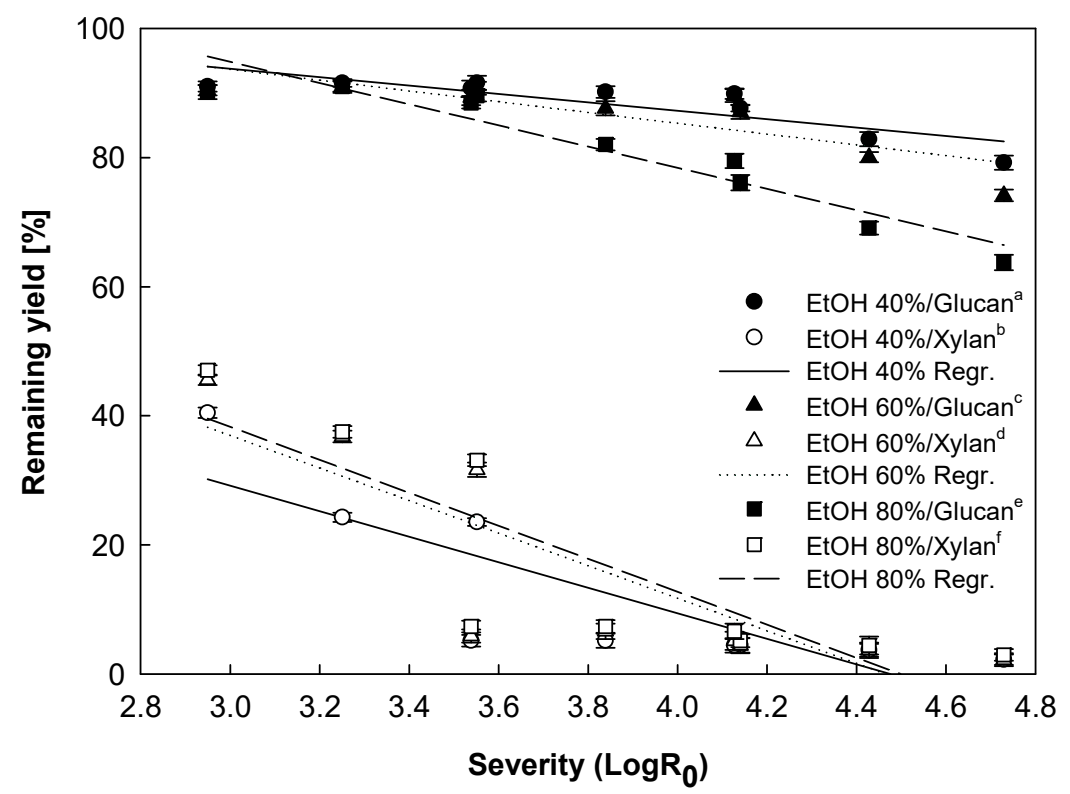

Figure 3. Remaining glucan and xylan yields with reaction severity ( $\log R_{0}$ from 2.95 to 4.73 ) and ethanol concentration. Reaction conditions: $150{ }^{\circ} \mathrm{C}, 170{ }^{\circ} \mathrm{C}$, and $190{ }^{\circ} \mathrm{C}$ for temperature; $30 \mathrm{~min}$, $60 \mathrm{~min}$, and $120 \mathrm{~min}$ for time; and 40\%, 60\%, and 80\% for ethanol concentrations; solid:liquid = 1:10; 0.25 wt.\% sulfuric acid concentration. Note the regression equations: $a: y=-6.5 x+113.2, b$ : $y=-19.8 x+88.5, c: y=-8.4 x+118.8, d: y=-25.2 x+112.5, e: y=-16.4 x+144.0$, and $f: y=-25.5 x+114.9$.

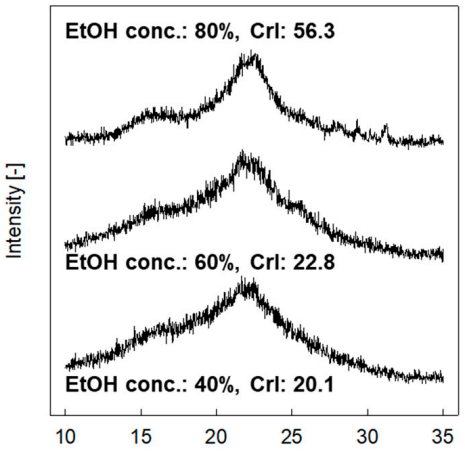

(a)

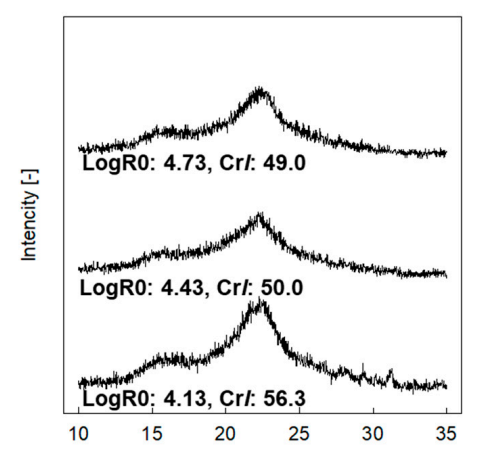

(b)

Figure 4. Diffraction patterns and CrIs (crystallinity indices) of organosolv-treated residual solids based on (a) ethanol concentration and (b) reaction severity $\left(\log R_{0}: 4.13,4.43\right.$, and 4.73). Reactions: (a) $190{ }^{\circ} \mathrm{C}$; $30 \mathrm{~min} ; 40 \%, 60 \%$, and $80 \%$ ethanol concentrations; solid:liquid $=1: 10 ; 0.25 \mathrm{wt}$. $\%$ sulfuric acid concentration. (b) $190{ }^{\circ} \mathrm{C}$; $30 \mathrm{~min}, 60 \mathrm{~min}$, and $120 \mathrm{~min}$; an $80 \%$ ethanol concentration; solid:liquid $=1: 10 ; 0.25 \mathrm{wt} . \%$ sulfuric acid concentration. 
Table 3. Effects of reaction temperature, time, and ethanol concentration on sugar and byproduct concentrations in liquid hydrolysate.

\begin{tabular}{|c|c|c|c|c|c|c|c|c|c|}
\hline \multicolumn{3}{|c|}{ Reaction Conditions } & \multicolumn{2}{|c|}{ Sugars } & \multicolumn{5}{|c|}{ Byproducts } \\
\hline Temp. & Time & Conc. & Glc & Xyl & $\begin{array}{c}\text { Formic } \\
\text { Acid }\end{array}$ & $\begin{array}{c}\text { Acetic } \\
\text { Acid }\end{array}$ & $\begin{array}{l}\text { Levulinic } \\
\text { Acid }\end{array}$ & 5-HMF & Furfural \\
\hline$\left({ }^{\circ} \mathrm{C}\right)$ & (min) & $(\%)$ & $(g / L)$ & $(g / L)$ & $(g / L)$ & $(g / L)$ & $(g / L)$ & $(g / L)$ & $(g / L)$ \\
\hline \multirow{9}{*}{150} & \multirow{3}{*}{30} & 40 & 2.3 & 10.4 & 0.3 & 1.1 & 0.1 & 0.0 & 0.7 \\
\hline & & 60 & 2.0 & 9.2 & 0.3 & 0.7 & 0.0 & 0.0 & 0.6 \\
\hline & & 80 & 1.4 & 8.8 & 0.3 & 0.6 & 0.1 & 0.0 & 0.6 \\
\hline & \multirow{3}{*}{60} & 40 & 3.0 & 10.6 & 0.3 & 0.8 & 0.2 & 0.0 & 0.8 \\
\hline & & 60 & 2.1 & 10.1 & 0.3 & 0.8 & 0.1 & 0.0 & 0.6 \\
\hline & & 80 & 1.5 & 9.8 & 0.4 & 0.7 & 0.1 & 0.0 & 0.7 \\
\hline & \multirow{3}{*}{120} & 40 & 2.6 & 10.6 & 0.3 & 1.1 & 0.2 & 0.1 & 1.0 \\
\hline & & 60 & 2.4 & 10.2 & 0.3 & 1.1 & 0.1 & 0.1 & 0.9 \\
\hline & & 80 & 2.3 & 9.9 & 0.3 & 0.7 & 0.1 & 0.0 & 0.7 \\
\hline \multirow{9}{*}{170} & \multirow{3}{*}{30} & 40 & 5.4 & 9.7 & 0.5 & 1.4 & 0.3 & 0.2 & 2.3 \\
\hline & & 60 & 5.4 & 9.7 & 0.7 & 1.1 & 0.3 & 0.2 & 1.8 \\
\hline & & 80 & 5.6 & 9.1 & 0.8 & 0.9 & 0.4 & 0.2 & 1.8 \\
\hline & \multirow{3}{*}{60} & 40 & 5.6 & 8.8 & 0.5 & 1.3 & 0.4 & 0.2 & 2.6 \\
\hline & & 60 & 5.7 & 8.1 & 0.5 & 1.0 & 0.4 & 0.2 & 2.3 \\
\hline & & 80 & 5.8 & 8.0 & 0.6 & 0.8 & 0.5 & 0.2 & 1.7 \\
\hline & \multirow{3}{*}{120} & 40 & 6.0 & 7.9 & 0.5 & 1.1 & 0.4 & 0.2 & 2.5 \\
\hline & & 60 & 6.4 & 8.3 & 0.6 & 1.1 & 0.4 & 0.2 & 2.4 \\
\hline & & 80 & 8.0 & 8.6 & 0.8 & 0.9 & 0.5 & 0.3 & 2.0 \\
\hline \multirow{9}{*}{190} & \multirow{3}{*}{30} & 40 & 3.7 & 8.1 & 0.4 & 0.9 & 0.4 & 0.0 & 1.9 \\
\hline & & 60 & 3.8 & 8.8 & 0.4 & 1.1 & 0.5 & 0.1 & 1.6 \\
\hline & & 80 & 4.9 & 9.3 & 0.7 & 0.9 & 0.5 & 0.1 & 1.8 \\
\hline & \multirow{3}{*}{60} & 40 & 4.9 & 6.6 & 0.6 & 1.3 & 0.6 & 0.2 & 2.5 \\
\hline & & 60 & 5.2 & 7.8 & 0.5 & 1.1 & 0.7 & 0.2 & 2.4 \\
\hline & & 80 & 8.6 & 7.6 & 0.8 & 0.8 & 0.8 & 0.3 & 2.1 \\
\hline & \multirow{3}{*}{120} & 40 & 4.6 & 3.1 & 0.7 & 1.3 & 0.9 & 0.4 & 3.7 \\
\hline & & 60 & 5.4 & 3.7 & 0.8 & 1.1 & 0.9 & 0.4 & 3.3 \\
\hline & & 80 & 9.2 & 4.8 & 1.0 & 1.0 & 1.0 & 0.4 & 3.1 \\
\hline
\end{tabular}

Reaction conditions: $150{ }^{\circ} \mathrm{C}, 170{ }^{\circ} \mathrm{C}$, and $190{ }^{\circ} \mathrm{C}$ for temperature; $30 \mathrm{~min}, 60 \mathrm{~min}$, and $120 \mathrm{~min}$ for time; and $40 \%$, $60 \%$, and $80 \%$ for ethanol concentrations; solid:liquid = 1:10; 0.25 wt. $\%$ sulfuric acid concentration.

The remaining xylan content in the organosolv-treated solid was directly proportional to the ethanol concentration and inversely proportional to $\log R_{0}$. Specifically, the remaining xylan yield was less than $1.0 \%$ from $\log R_{0} 3.54$ to 4.73 . However, despite the $\log R_{0}$ of 3.54 and 3.55 , there was a significant difference in the remaining xylan content, which was similar to the result for delignification in Section 3.1.1. For example, the two reaction conditions at $\log R_{0} 3.55$ and 3.54 at the $40 \%$ ethanol concentration were $150{ }^{\circ} \mathrm{C} / 120 \mathrm{~min}$ and $170{ }^{\circ} \mathrm{C} / 30 \mathrm{~min}$, and the remaining xylan yields under each fractionation condition were $23.5 \%$ and $5.1 \%$, respectively. This indicates that both delignification and xylan dissolution were more affected by the reaction temperature than by the reaction time, and delignification and xylan hydrolysis were correlated.

The degree of sugar decomposition during organosolv fractionation can be considered as a criterion for determining the severity of the reaction. The concentrations of furfural and acetic acid produced by the decomposition and hydrolysis of xylose were measured by HPLC, which decreased with an increasing ethanol concentration (Table 3). This indicates that a low ethanol concentration may render a more severe reaction condition in organosolv fractionation than that rendered with a high ethanol concentration. By contrast, formic acid and levulinic acid appeared to be directly proportional to the ethanol concentration. Formic acid and levulinic acid are generally generated by the decomposition of cellulose, and this phenomenon was likely caused by the relatively high dissolution of glucose at high ethanol concentrations $[33,34]$. 


\subsubsection{Lignin Properties}

To understand the properties of the lignin precipitated under the fractionation reaction, the concentrations of hydroxyl groups in lignin and molecular weight were analyzed via ${ }^{31} \mathrm{P}$ NMR and GPC, respectively, and are presented in Table 4 . The table shows that the hydroxyl groups of lignin were increased as the reaction temperature increased from $150{ }^{\circ} \mathrm{C}$ to $190^{\circ} \mathrm{C}$. The differences between the $\mathrm{H}, \mathrm{G}$, and $\mathrm{S}$ lignin units in the samples treated at the lowest temperature $\left(150^{\circ} \mathrm{C}\right)$ and the highest temperature $\left(190^{\circ} \mathrm{C}\right)$ were $0.22 \mathrm{mmol} / \mathrm{g}$, $0.62 \mathrm{mmol} / \mathrm{g}$, and $0.82 \mathrm{mmol} / \mathrm{g}$, respectively. By contrast, the aliphatic hydroxyl groups in the lignin decreased as the reaction temperature increased and decreased by $1.37 \mathrm{mmol} / \mathrm{g}$ at the highest temperature $\left(190^{\circ} \mathrm{C}\right)$ compared to the lowest temperature $\left(150^{\circ} \mathrm{C}\right)$. In the carboxyl group, drastic changes did not occur under organosolv fractionation with all of the reaction conditions. As the reaction time increased, while maintaining the reaction temperature and ethanol concentration at $170{ }^{\circ} \mathrm{C}$ and $80 \%$ respectively, the hydroxyl groups of the lignin increased. The differences in the $\mathrm{H}, \mathrm{G}$, and $\mathrm{S}$ units between the shortest reaction time (30 $\mathrm{min}$ ) and the longest reaction time $(120 \mathrm{~min})$ were $0.14 \mathrm{mmol} / \mathrm{g}$, $0.22 \mathrm{mmol} / \mathrm{g}$, and $0.33 \mathrm{mmol} / \mathrm{g}$, respectively. Conversely, the aliphatic hydroxyl groups decreased as the reaction temperature increased, where it decreased by $0.32 \mathrm{mmol} / \mathrm{g}$ at the longest reaction time $(120 \mathrm{~min})$ compared to the shortest reaction time (30 $\mathrm{min})$. Therefore, the lignin characteristics according to the various reaction temperatures and reaction times were similar, and the $S$ unit contents were more sensitive to various reaction severities than the $\mathrm{H}$ and $\mathrm{G}$ units. By contrast, no significant change was observed with varying ethanol concentrations. The hydroxyl group contents with $40 \%, 60 \%$, and $80 \%$ ethanol concentrations in organosolv fractionation were $3.42 \mathrm{mmol} / \mathrm{g}, 2.75 \mathrm{mmol} / \mathrm{g}$, and $3.37 \mathrm{mmol} / \mathrm{g}$, respectively, and there was no significant trend. Regarding the ethanol concentration, two factors, reaction severity and lignin solubility, had complex reaction mechanisms. Therefore, it is necessary to investigate the correlation for each factor through a more specific reaction condition experiment.

Table 4. Effects of reaction temperature, time, and ethanol concentration on hydroxyl groups and molecular weight of precipitated lignin.

\begin{tabular}{|c|c|c|c|c|c|c|c|c|c|c|c|}
\hline \multicolumn{3}{|c|}{ Reaction Conditions } & \multicolumn{6}{|c|}{ Hydroxyl Groups } & \multicolumn{3}{|c|}{ Molecular Weight } \\
\hline Temp & Time & Conc. & Aliphatic & $\mathrm{H}^{1}$ Unit & $\mathrm{G}^{2}$ Unit & $\mathrm{S}^{3}$ Unit & Phenols & $\mathrm{COOH}$ & $M_{n}^{4}$ & $M_{w}{ }^{5}$ & PDI $^{6}$ \\
\hline$\left({ }^{\circ} \mathrm{C}\right)$ & (min) & $(\%)$ & $(\mathrm{mmol} / \mathrm{g})$ & $(\mathrm{mmol} / \mathrm{g})$ & $(\mathrm{mmol} / \mathrm{g})$ & $(\mathrm{mmol} / \mathrm{g})$ & $(\mathrm{mmol} / \mathrm{g})$ & $(\mathrm{mmol} / \mathrm{g})$ & (g/mol) & (g/mol) & $(-)$ \\
\hline 150 & \multirow{3}{*}{120} & \multirow{3}{*}{80} & 2.24 & 0.50 & 0.87 & 0.52 & 1.90 & 0.12 & 1886 & 3970 & 2.10 \\
\hline 170 & & & 1.03 & 0.60 & 1.44 & 1.33 & 3.37 & 0.15 & 1308 & 1839 & 1.41 \\
\hline 190 & & & 0.87 & 0.72 & 1.49 & 1.34 & 3.55 & 0.13 & 1275 & 1782 & 1.40 \\
\hline \multirow{3}{*}{170} & 30 & \multirow{3}{*}{80} & 1.35 & 0.46 & 1.22 & 1.00 & 2.68 & 0.08 & 1340 & 1870 & 1.40 \\
\hline & 60 & & 1.12 & 0.58 & 1.42 & 1.19 & 3.19 & 0.15 & 1319 & 1881 & 1.43 \\
\hline & 120 & & 1.03 & 0.60 & 1.44 & 1.33 & 3.37 & 0.15 & 1308 & 1839 & 1.41 \\
\hline \multirow{3}{*}{170} & \multirow{3}{*}{120} & 40 & 1.26 & 0.66 & 1.46 & 1.29 & 3.42 & 0.26 & 1116 & 1384 & 1.24 \\
\hline & & 60 & 1.05 & 0.55 & 1.16 & 1.04 & 2.75 & 0.25 & 1244 & 1655 & 1.33 \\
\hline & & 80 & 1.03 & 0.60 & 1.44 & 1.33 & 3.37 & 0.15 & 1308 & 1839 & 1.41 \\
\hline
\end{tabular}

\footnotetext{
${ }^{1} \mathrm{H}$ unit: $p$-hydroxyphenyl, ${ }^{2} \mathrm{G}$ unit: Guaiacyl, ${ }^{3} \mathrm{~S}$ unit: Syringyl, ${ }^{4} M_{n}$ : Number-average molar mass, ${ }^{5} M_{w}$ : Weight-average molar mass,
}

${ }^{6}$ PDI: Polydispersity index $\left(M_{w} / M_{n}\right)$.

The GPC profile of precipitated lignin on various reaction conditions are presented in Figure S1. In the case of the molecular weight of the lignin generated by organosolv fractionation (shown in Table 4), the $M_{n}, M_{w}$, and PDI values tended to decrease from $1886 \mathrm{~g} / \mathrm{mol}$ to $1275 \mathrm{~g} / \mathrm{mol}, 3970 \mathrm{~g} / \mathrm{mol}$ to $1782 \mathrm{~g} / \mathrm{mol}$, and 2.10 to 1.40 , respectively, as the reaction temperature increased. In general, organosolv lignin is known to have a low molecular weight $\left(M_{n}: 700-1550 \mathrm{~g} / \mathrm{mol}\right)$ and a low polydispersity index [6,32]. These facts suggest that the results obtained in this paper have a reliable lignin molecular weight range. Over the tested temperature range $\left(150-190^{\circ} \mathrm{C}\right)$, the differences in the $M_{n}, M_{w}$, and 
PDI values were $611 \mathrm{~g} / \mathrm{mol}, 2188 \mathrm{~g} / \mathrm{mol}$, and 0.7, respectively. By contrast, the molecular weights of the lignin for the tested reaction times did not show substantial differences, unlike for the reaction temperatures. The differences in the $M_{n}, M_{w}$, and PDI values between the two reaction times (30 min and $120 \mathrm{~min}$ ) were only $32 \mathrm{~g} / \mathrm{mol}, 31 \mathrm{~g} / \mathrm{mol}$, and 0.01 , respectively. As the ethanol concentration increased, the $M_{n}, M_{w}$, and PDI values increased from $1116 \mathrm{~g} / \mathrm{mol}$ to $1308 \mathrm{~g} / \mathrm{mol}, 1384 \mathrm{~g} / \mathrm{mol}$ to $1839 \mathrm{~g} / \mathrm{mol}$, and 1.24 to 1.41 , respectively. Based on the above results, an increase in the reaction severity (a function of the reaction temperature and time) tended to generate a lower molecular weight for lignin. Conversely, increasing the ethanol concentration and reducing the reaction severity did not result in lowering the molecular weight of the lignin. Based on these results, the molecular weight of the extracted lignin highly depends on the reaction severity, and the molecular weight of the lignin is significantly affected by the factors in the order of reaction temperature, ethanol concentration, and reaction time.

\subsection{Overall Mass Balance}

The mass balance of the precipitated lignin was calculated and is shown in Table 5; conditions 1 and 2 represent the preferred conditions for sugar and lignin, respectively. Under condition 1, more sugars were recovered; more specifically, $91.5 \%$ of the glucan was retained in the residual solid, and $75.2 \%$ of the xylose and $22.8 \%$ of the lignin (precipitated) were recovered from the liquid hydrolysate. Contrastingly, in condition 2 (more lignin recovery), $73.8 \%$ of the glucan was preserved in the residual solid, and $63.1 \%$ and $59.7 \%$ of the xylose and lignin were obtained in the liquid hydrolysate. In terms of the sugars extracted mass balances (EMBs), that in condition 1 was higher than $99.5 \%$, whereas condition 2 showed lower values (for glucan of $96.8 \%$ and xylan of $67.5 \%$ ), which was attributed to a higher sugar degradation reaction caused by the stronger reaction severity of condition 2 compared to condition 1 . The extraction mass balances of lignin were $77.0 \%$ and $76.4 \%$, respectively, for conditions 1 and 2 . In addition, even though lignin recovery by precipitation was attempted, the lower lignin EMB likely occurred because a large amount of solubilized lignin (small molecular size) remained in the liquid hydrolysate.

Table 5. Extraction mass balances of glucan, xylan, and lignin following the process of organosolv fractionation from rice husks under optimal conditions.

\begin{tabular}{|c|c|c|c|c|c|c|c|c|c|c|c|}
\hline \multirow{2}{*}{\multicolumn{2}{|c|}{ Classification }} & \multirow{2}{*}{$\begin{array}{c}\text { Solids } \\
\text { Remaining (\%) }\end{array}$} & \multicolumn{3}{|c|}{ Solid (\%) } & \multicolumn{3}{|c|}{ Liquid (\%) } & \multicolumn{3}{|c|}{ EMB $^{1}(\%)$} \\
\hline & & & Glucan & Xylan & Lignin & Glucan & Xylan & Lignin & Glucan & Xylan & Lignin \\
\hline & treated & 100 & 35.5 & 13.6 & 22.7 & - & - & - & & & \\
\hline \multirow[b]{2}{*}{ Cond. $1^{2}$} & Fractionated & \multirow[t]{2}{*}{67.8} & 48.0 & 6.4 & 18.2 & 2.9 & 10.2 & 5.2 & \multirow[t]{2}{*}{99.8} & \multirow[t]{2}{*}{99.5} & \multirow[t]{2}{*}{77.0} \\
\hline & $\begin{array}{l}\text { Fractionated }{ }^{4} \\
\text { Component }\end{array}$ & & $\begin{array}{l}32.5 \\
91.5\end{array}$ & $\begin{array}{c}3.3 \\
24.3\end{array}$ & $\begin{array}{l}12.3 \\
54.2\end{array}$ & $\begin{array}{l}2.9 \\
-\end{array}$ & $\begin{array}{l}10.2 \\
-\end{array}$ & 0.2 & & & \\
\hline \multirow{2}{*}{ Cond. $2^{3}$} & $\begin{array}{l}\text { Fractionated } \\
\text { Fractionated } 4\end{array}$ & 50.4 & 52.0 & 1.1 & $\begin{array}{l}7.5 \\
3.8\end{array}$ & 8.2 & 8.6 & 13.6 & 96.8 & 67.5 & 76.4 \\
\hline & Component & Retention (\%) & 73.8 & 4.4 & $\begin{array}{c}5.0 \\
16.7\end{array}$ & - & - & - & - & - & - \\
\hline
\end{tabular}

${ }^{1}$ Extracted mass balance $(E M B)=\left(\sum C_{L i}+\sum C_{S i}\right) /\left(\sum C_{R i}\right)$, where $C_{i}$ is the mass of each sugar component, and $C_{L i}$ was determined through HPLC. The subscripts L, S, and R refer to the extracted liquid, fractionated solids, and raw rice husk fractions, respectively. ${ }^{2}$ Condition 1 (Cond. 1): reaction temperature of $150{ }^{\circ} \mathrm{C}$, reaction time of $60 \mathrm{~min}$, ethanol concentration of $40 \%$. ${ }^{3} \mathrm{Condition} 2$ (Cond. 2 ): reaction temperature of $170{ }^{\circ} \mathrm{C}$, reaction time of $120 \mathrm{~min}$, ethanol concentration of $80 \% .{ }^{4}$ Data are based on the oven-dried untreated biomass.

\section{Conclusions}

Various reaction conditions were applied to evaluate the organosolv-fractionation process for producing value-added products from RHs. The extraction behavior of the main components of RHs, such as cellulose, hemicellulose (mainly xylose), and lignin, was closely related to the reaction parameters (reaction temperature, time, and ethanol concentration) during the organosolv-fractionation process. Specifically, the ethanol concentration causes a tradeoff relationship between lignin precipitation and carbohydrate extraction yields, 
which strongly suggests that appropriate reaction conditions should be applied depending on the target product. Therefore, the behavioral characteristics discussed in this study are the basic data needed to improve the added value of RHs.

Supplementary Materials: The following are available online at https:/ /www.mdpi.com/1996-107 3/14/3/686/s1, Figure S1: GPC profile of precipitated lignin on various reaction conditions (reaction temperature, time and ethanol concentration); (a) $150{ }^{\circ} \mathrm{C}, 120 \mathrm{~min}, 80 \%$, (b) $170{ }^{\circ} \mathrm{C}, 120 \mathrm{~min}, 80 \%$, (c) $190{ }^{\circ} \mathrm{C}, 120 \mathrm{~min}, 80 \%$, (d) $170{ }^{\circ} \mathrm{C}, 30 \mathrm{~min}, 80 \%$, (e) $170{ }^{\circ} \mathrm{C}, 60 \mathrm{~min}, 80 \%$, (f) $170{ }^{\circ} \mathrm{C}, 120 \mathrm{~min}, 40 \%$, (g) $170{ }^{\circ} \mathrm{C}, 120 \mathrm{~min}, 60 \%$.

Author Contributions: T.H.K. (Tae Hoon Kim), as the first author, conducted all the experiments, summarized the data, and drafted the manuscript. H.K. conducted experiments and analyzed the data. T.H.K. (Tae Hyun Kim) and K.K.O., as the co-corresponding authors, equally contributed; specifically, they designed the reactor system as well as the overall study and experiments, interpreted the results, wrote the manuscript, and finalized the manuscript. All authors have read and agreed to the published version of the manuscript.

Funding: This research was supported by the Technology Development Program to Solve Climate Changes of the National Research Foundation (NRF) funded by the Ministry of Science and ICT (2017M1A2A2087627).

Conflicts of Interest: The authors declare no conflict of interest.

\section{References}

1. Da Silva, A.R.G.; Errico, M.; Rong, B.G. Evaluation of organosolv pretreatment for bioethanol production from lignocellulosic biomass: Solvent recycle and process integration. Biomass Convers. Biorefin. 2018, 8, 397-411. [CrossRef]

2. Vu, H.P.; Nguyen, L.N.; Vu, M.T.; Johir, M.A.H.; McLaughlan, R.; Nghiem, L.D. A comprehensive review on the framework to valorise lignocellulosic biomass as biorefinery feedstocks. Sci. Total Environ. 2020, 743, 140630. [CrossRef]

3. Kim, T.H.; Kim, T.H. Overview of technical barriers and implementation of cellulosic ethanol in the US. Energy 2014, 66, 13-19. [CrossRef]

4. Dragone, G.; Kerssemakers, A.A.; Driessen, J.L.; Yamakawa, C.K.; Brumano, L.P.; Mussatto, S.I. Innovation and strategic orientations for the development of advanced biorefineries. Bioresour. Technol. 2020, 302, 122847. [CrossRef]

5. Ubando, A.T.; Africa, A.D.M.; Maniquiz-Redillas, M.C.; Culaba, A.B.; Chen, W.H. Reduction of particulate matter and volatile organic compounds in biorefineries: A state-of-the-art review. J. Hazard. Mater. 2020, 403, 123955. [CrossRef]

6. Mussatto, S.I. (Ed.) Biomass Fractionation Technologies for a Lignocellulosic Feedstock Based Biorefinery; Elsevier Inc.: Waltham, MA, USA, 2016; p. 674. ISBN 9780128023235.

7. De Jong, E.; Jungmeier, G. Biorefinery Concepts in Comparison to Petrochemical Refineries. In Industrial Biorefineries $\mathcal{E}$ White Biotechnology; Pandey, A., Höfer, R., Taherzadeh, M., Nampoothiri, K.M., Larroche, C., Eds.; Elsevier: Amsterdam, The Netherlands, 2015; pp. 3-33. [CrossRef]

8. Bozell, J.J.; Petersen, G.R. Technology development for the production of biobased products from biorefinery carbohydrates-the US Department of Energy's “Top 10" revisited. Green Chem. 2010, 12, 539-554. [CrossRef]

9. Bio Based Chemicals (IEA Energy); Jong, E.D.; Higson, A.; Walsh, P.; Maria, W. Bio-Based Chemicals: Value Added Products from Biorefineries; Report on Behalf of the International Energy Agency (IEA) Bioenergy; IEA Energy: Wageningen, The Netherlands, February 2010; Available online: https: / / www.ieabioenergy.com/publications/bio-based-chemicals-value-added-productsfrom-biorefineries / (accessed on 2 November 2020).

10. Davis, K.M.; Rover, M.; Brown, R.C.; Bai, X.; Wen, Z.; Jarboe, L.R. Recovery and utilization of lignin monomers as part of the biorefinery approach. Energies 2016, 9, 808. [CrossRef]

11. Chen, H.; Liu, J.; Chang, X.; Chen, D.; Xue, Y.; Liu, P.; Han, S. A review on the pretreatment of lignocellulose for high-value chemicals. Fuel Process. Technol. 2017, 160, 196-206. [CrossRef]

12. Zabed, H.; Sahu, J.N.; Boyce, A.N.; Faruq, G. Fuel ethanol production from lignocellulosic biomass: An overview on feedstocks and technological approaches. Renew. Sustain. Energy Rev. 2016, 66, 751-774. [CrossRef]

13. Zhang, Z.; Harrison, M.D.; Rackemann, D.W.; Doherty, W.O.; O'Hara, I.M. Organosolv pretreatment of plant biomass for enhanced enzymatic saccharification. Green Chem. 2016, 18, 360-381. [CrossRef]

14. Sun, W.; Trevorah, R.; Othman, M.Z. Fractionation of spent liquor from organosolv-pretreatment using lignin-incompatible extraction. Bioresour. Technol. 2018, 269, 255-261. [CrossRef]

15. Fahad, S.; Adnan, M.; Noor, M.; Arif, M.; Alam, M.; Khan, I.A.; Basir, A. Major constraints for global rice production. In Advances in Rice Research for Abiotic Stress Tolerance; Hasanuzzaman, M., Fujita, M., Nahar, K., Biswas, J.K., Eds.; Woodhead Publishing: Cambridge, UK, 2019; pp. 1-22. [CrossRef]

16. Muthayya, S.; Sugimoto, J.D.; Montgomery, S.; Maberly, G.F. An overview of global rice production, supply, trade, and consumption. Ann. N. Y. Acad. Sci. 2014, 1324, 7-14. [CrossRef] 
17. Lim, J.S.; Manan, Z.A.; Alwi, S.R.W.; Hashim, H. A review on utilisation of biomass from rice industry as a source of renewable energy. Renew. Sustain. Energy Rev. 2012, 16, 3084-3094. [CrossRef]

18. Zhang, H.; Ding, X.; Chen, X.; Ma, Y.; Wang, Z.; Zhao, X. A new method of utilizing rice husk: Consecutively preparing d-xylose, organosolv lignin, ethanol and amorphous superfine silica. J. Hazard. Mater. 2015, 291, 65-73. [CrossRef]

19. Sluiter, A.; Ruiz, R.; Scarlata, C.; Sluiter, J.; Templeton, D. Determination of Extractives in Biomass; NREL/TP-510-42619; National Renewable Energy Laboratory: Golden, CO, USA, 2008.

20. Sluiter, A.; Hames, B.; Ruiz, R.; Scarlata, C.; Sluiter, J.; Templeton, D. Determination of Structural Carbohydrates and Lignin in Biomass; NREL/TP-510-42618; National Renewable Energy Laboratory: Golden, CO, USA, 2012.

21. Sluiter, A.; Hames, B.; Ruiz, R.; Scarlata, C.; Sluiter, J.; Templeton, D. Determination of Ash in Biomass; NREL/TP-510-42622; National Renewable Energy Laboratory: Golden, CO, USA, 2008.

22. Sluiter, A.; Hames, B.; Ruiz, R.; Scarlata, C.; Sluiter, J.; Templeton, D. Determination of Sugars, Byproducts, and Degradation Products in Liquid Fraction Process Samples; NREL/TP-510-42623; National Renewable Energy Laboratory: Golden, CO, USA, 2008.

23. Zhang, K.; Pei, Z.; Wang, D. Organic solvent pretreatment of lignocellulosic biomass for biofuels and biochemicals: A review. Bioresour. Technol. 2016, 199, 21-33. [CrossRef]

24. Schulze, P.; Seidel-Morgenstern, A.; Lorenz, H.; Leschinsky, M.; Unkelbach, G. Advanced process for precipitation of lignin from ethanol organosolv spent liquors. Bioresour. Technol. 2016, 199, 128-134. [CrossRef]

25. Ni, Y.; Hu, Q. Alcell ${ }^{\circledR}$ lignin solubility in ethanol-water mixtures. J. Appl. Polym. Sci. 1995, 57, 1441-1446. [CrossRef]

26. Overend, R.P.; Chornet, E. Fractionation of lignocellulosics by steam-aqueous pretreatments. Philos. Trans. R. Soc. A Math. Phys. Eng. Sci. 1987, 321, 523-536. [CrossRef]

27. Cao, Y.; Tan, H. Study on crystal structures of enzyme-hydrolyzed cellulosic materials by X-ray diffraction. Enzym. Microb. Technol. 2005, 36, 314-317. [CrossRef]

28. Dagnino, E.P.; Felissia, F.E.; Chamorro, E.; Area, M.C. Optimization of the soda-ethanol delignification stage for a rice husk biorefinery. Ind. Crop. Prod. 2017, 97, 156-165. [CrossRef]

29. Kim, D.E.; Pan, X. Preliminary study on converting hybrid poplar to high-value chemicals and lignin using organosolv ethanol process. Ind. Eng. Chem. 2010, 49, 12156-12163. [CrossRef]

30. Kim, T.H.; Ryu, H.J.; Oh, K.K. Improvement of organosolv fractionation performance for rice husk through a low acid-catalyzation. Energies 2019, 12, 1800. [CrossRef]

31. Singh, S.K.; Dhepe, P.L. Effect of structural properties of organosolv lignins isolated from different rice husks on their liquefaction using acidic ionic liquids. Clean Technol. Environ. Policy 2018, 20, 739-750. [CrossRef]

32. Singh, S.K.; Dhepe, P.L. Isolation of lignin by organosolv process from different varieties of rice husk: Understanding their physical and chemical properties. Bioresour. Technol. 2016, 221, 310-317. [CrossRef]

33. Pan, X.; Xie, D.; Yu, R.W.; Lam, D.; Saddler, J.N. Pretreatment of lodgepole pine killed by mountain pine beetle using the ethanol organosolv process: Fractionation and process optimization. Ind. Eng. Chem. 2007, 46, 2609-2617. [CrossRef]

34. Tolbert, A.; Akinosho, H.; Khunsupat, R.; Naskar, A.K.; Ragauskas, A.J. Characterization and analysis of the molecular weight of lignin for biorefining studies. Biofuels Bioprod. Biorefin. 2014, 8, 836-856. [CrossRef] 